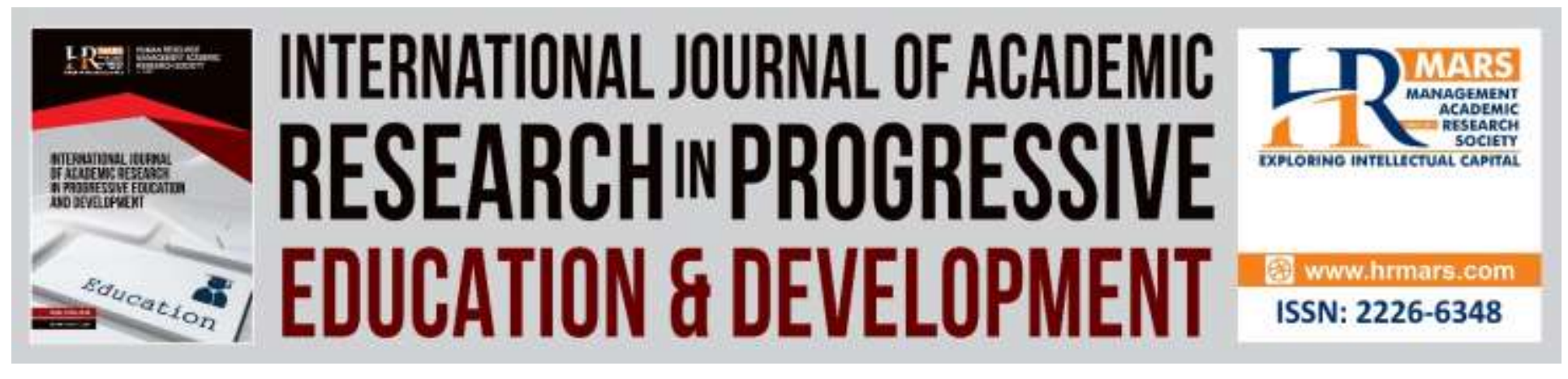

\title{
Generic Skills: Concept and Importance of Students Mastery
}

Maizatul Suraya Muhammad Nor, Mohd Isa Hamzah, Khadijah Abdul Razak \& Fatahiyah Elias

To Link this Article: http://dx.doi.org/10.6007/IJARPED/v8-i2/6442

DOI: 10.6007/IJARPED/v8-i2/6442

Received: 17 March 2019, Revised: 09 April 2019, Accepted: 15 April 2019

Published Online: 28 April 2019

In-Text Citation: (Nor, Hamzah, Razak, \& Elias, 2019)

To Cite this Article: Nor, M. S. M., Hamzah, M. I., Razak, K. A., \& Elias, F. (2019). Generic Skills: Concept and Importance of Students Mastery. International Journal of Academic Research in Progressive Education and Development, 8(2), 515-524.

Copyright: (C) 2019 The Author(s)

Published by Human Resource Management Academic Research Society (www.hrmars.com)

This article is published under the Creative Commons Attribution (CC BY 4.0) license. Anyone may reproduce, distribute, translate and create derivative works of this article (for both commercial and non-commercial purposes), subject to full attribution to the original publication and authors. The full terms of this license may be seen

at: http://creativecommons.org/licences/by/4.0/legalcode

\section{Vol. 8(2) 2019, Pg. 515 - 524}

http://hrmars.com/index.php/pages/detail/IJARPED

JOURNAL HOMEPAGE

Full Terms \& Conditions of access and use can be found at http://hrmars.com/index.php/pages/detail/publication-ethics 


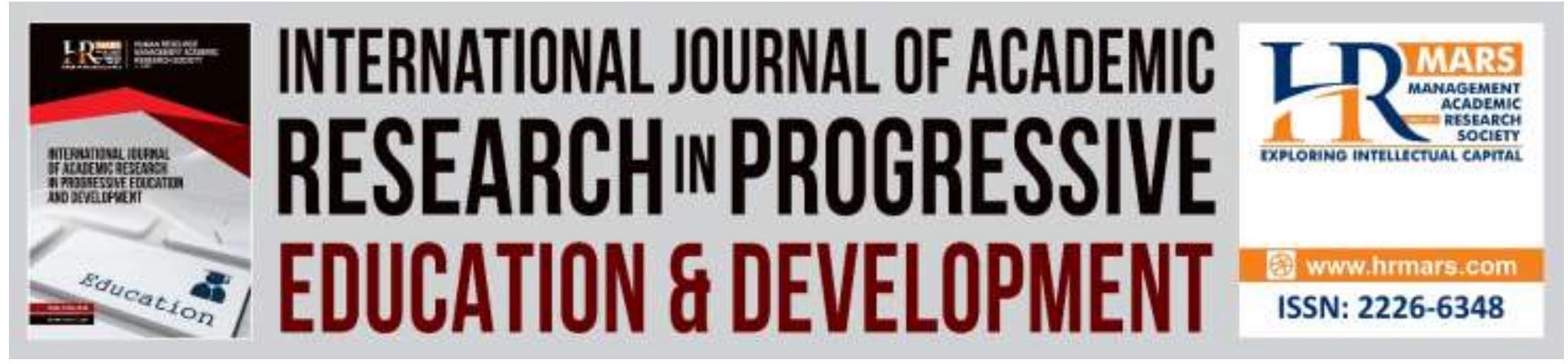

\title{
Generic Skills: Concept and Importance of Students Mastery
}

\author{
Maizatul Suraya Muhammad Nor, Mohd Isa Hamzah, Khadijah \\ Abdul Razak \& Fatahiyah Elias \\ Faculty of Education, The National University of Malaysia, 43600 UKM Bangi, Selangor
}

\begin{abstract}
This article is based on previous studies regarding generic skills that embody the concept of generic skills, issues in generic skills and the importance of mastering the skills. In terms of concept, it will be described in respect of the definition of generic skills and abroad. In addition, the generic skills are described from the perspective of Islam, the prophet generic skills, issues related to the importance of generic skills and final mastering generic skills to students. Further research is also needed to explore the practice of generic skills practiced level of schooling, especially in dealing with the industrial revolution 4.0 and 21st century education that emphasizes human capital that is useful for the country.
\end{abstract}

Keywords: Generic Skills, Concepts, Importance, Control

\section{Introduction}

There are various definitions to describe the generic skills, but in this article the definition of generic skills will be divided into two, namely the definition of the national aspect and foreign researchers.

\section{Domestic Definition}

According to Abbas (2008), this skill is as a general skill, the quality, the ability to combine the main areas of knowledge or service to make a person better (Rippin et.al, (2012) is non-academic and more focused on the development of the individual, personality and humanity.

Arsat \& Rahimi (2011) defines the generic skills or soft skills with focus in terms of behavior, communication skills, attitude, ability to solve a problem, and how to obtain results related to organizational management. In industry, they are called as skills availability of Labor Acts (Rasul et.al, 2014) or "Employability Skills". 


\section{Abroad Definition}

Generic skills have long been used in foreign countries. In the United States, for example, they have introduced generic skills since the 1990's. These skills are known as basic skills, necessary skills, employability skills or know-how workplace. United Kingdom on the other hand, uses the term key skills or core skills (Clayton et. al, 2003) common skills (Wibrow, 2011). Meanwhile, Kearns (2001) concluded that generic skills goes beyond all range of jobs. Skills including competence, cognitive, personal and interpersonal skills that match the job marketability. Nabi \& Bagley (1998) divides the generic skills into three parts, namely, personal skills, problem solving skills and communication skills.

Generally, generic skills are the skills possessed apart from studies and technical fields of study. It is an added value to the students in preparation for the real working environment and are considered competent if students have the soft skills. Mostly related skills such as leadership, teamwork, communication skills and continuous learning (Department of Institutional Management of Higher Education, 2006). It is especially the essential skills for graduates to improve their performance (Ahmad et. al, 2015).

\section{Generic Skills by Islamic Perspective}

Islam does not put a limitation in the pursuit of knowledge. Islam is flexible, suitable for all places and circumstances. Umar al-Khattab said;

"Bring your children with the condition which you are different because they have made God for the time period you are not."

Islam does not see education from a narrow scope, it is not limited to purely secular education even field which includes two of the worlds and the hereafter (Stapa, 2012). Islam has laid down three basic education that is based on the science of the mind (cognitive), heart (effective) and jawarian (psychomotor). The three policy must be based on the Quran, Sunnah and ijtihad of scholars (Darulsalam, 2004). Muslims need to learn a variety of knowledge to improve themselves and need to be on par with other races. Those who diligently seek to claim the knowledge above all else shall be appointed by Allah SWT grades:

"Allah will raise the degree of those who have knowledge among you) some degree".

(Surah al-Mujadalah, 58:11)

The above verse describes the goal of education is to obtain a degree or human height as the vicegerent of Allah (Darulsalam, 2004). Through science, too, will produce good skills that can improve the quality of output or employment income (Ripin et. al, 2012). Through the various branches of knowledge, will produce the skills that are needed by humans. Muslims who have multiple skills will be more forward than those who are skilled in one area only. The advent of the era of excellence in science and education during the reign of Islam has shown how relevant Islamic education based on knowledge of it and supported by science aqal (Suhid, 2007). Islam 
Vol. 8, No. 2, 2019, E-ISSN: 2226-6348 @ 2019 HRMARS

emphasizes many skills in life. In the Holy Quran there are many verses that urge to have skills in work and life. One verse in Surah al-Zumar, 9 which means;

Say; whether the same people who know and those who know not? But those who can grasp the Message except those of understanding.

Skill is a science that needs to be worked on (Ripin et. al, 2012). According to him, science is internal in nature, while skills are manifestations of external nature. For example, an employee who is good at academics, but failed in terms of communication, then he will not be able to advance the company. Therefore, the mastery of knowledge and skills are necessary to run concurrently.

\section{Generic Skills of the Prophets}

Islam came with the complete package and is perfect which is through the sending of prophets and apostles as a guide for mankind to the right path. The sending of prophets and apostles in immortalized in the word of God;

\section{"And verily We sent messengers to call worship Allah and avoid evil".}

(Surat al-Nahl verse 16)

The prophets who were sent comes with good moral perfection, knowledge and high skills to prove that Islam is the best all-inclusive philosophy of life. In addition to a higher knowledge, they are also equipped with skills that can serve as an example to other Muslims. Prophet Idris as, for example, is one of the prophets who were given skills who can speak various languages. An estimated 70 languages are spoken by his prophet Idris to be preached (Ripin et. al, 2012). In addition to the power of the multi-language speech, he is also great in the science of math skills. Noah is an expert in a variety of knowledge and skills. Skill is the history of the Muslims which enables them to recognize and carpentry craft different types of wood that are resistant to serve as shipbuilding materials. Word of God;

"Noah and the Ark was made, and every time that chieftains of his people passed by the ark that they build, they laughed in mockery. He said: "If you ridicule us (for making this ark), then we will look foolish (not in default), as (children) will ridicule you".

(Surah Hud, 11:38)

In addition, versed in shipbuilding, prophet Noah is also a specialist in industry and agriculture and animal husbandry in the agriculture industry (Darulsalam, 2004). The story of the prophet Hud and his people in the history of Islam can provide a role model for the Muslims. By having the strength of body physique and high science skills, they were allowed by God to build a large building with columns which are very high. As Allah says which means:

"Have you not seen how your Lord dealt with Ad? (That is) the occupation of Iram who have high-rise buildings. That has never built (a town) as it was, the land of other states ". 
INTERNATIONAL JOURNAL OF ACADEMIC RESEARCH IN PROGRESSIVE EDUCATION AND DEVELOPMENT

Vol. 8, No. 2, 2019, E-ISSN: 2226-6348 @ 2019 HRMARS

(Surah al-Fajr 89: 6-8)

They are also blessed with God's aesthetic and artistic skills in literature, science and culture (Darulsalam, 2004). Salleh as the prophet of God who was endowed with strong thinking skills.

"People said: O Salih, before this you were one of us as we had hoped, do you forbid us to worship what our fathers worshipped? And we really are in grave doubt as to that which you invite us. ".

(In Surah Hud 11:62)

Skills make armor out of woven steel is a skill possessed by the prophet David, as he was the first man to have the skills to create armor to armor designed facilitate the wearer to wear due to the light armor he created (Ripin, 2012), Al-Quran capture this story as Allah says:

"And we also made the iron soft for him; and we inspired him: make coats of mail and measure their links well be required; and do you (O Daud and thy people) good deeds, truly, I am loving look all that you do.'

(Surah Saba' 34:11-12)

Examples of skills that God gave to the prophets and messengers is a great indicator. Therefore, as Muslims, we should make the prophets and apostles as an idol and a role model of all time to be successful in this life and the hereafter.

\section{Issues in Generic Skills}

Department of Statistics (2016) stated that the unemployment rate in August 2016 was 3.5\%, similar to that that was recorded in the previous month. However, comparisons between the years, the unemployment rate is higher at 0.3 percentage point more than in August 2015. Unemployed graduates are said to not have a package that allows them admission to the occupation because they do not have the necessary skills or skills that are not appropriate according to the will of the employer (Amla, 2010) as generic skills as well as technical skills (Khir, 2006).

Mismatch and balance skills has three levels according to the study (Regel et. al, 2007), namely, a) the balance in supply and demand between disciplines (such as humanities, science and engineering), b) the balance between technical skills and generic or soft and c ) balance between theory and practice-oriented education and training received. Some of the skills mismatch is the result of individual career choices in terms of priorities related to the field of study and work. Skills mismatch can also arise from weaknesses by tertiary education institutions in the form of quality of education, faculty and pedagogy, in the delivery of academic programs tailored to the needs of the market and whether the career counseling that are provided to students (Regel et. al, 2007). 
INTERNATIONAL JOURNAL OF ACADEMIC RESEARCH IN PROGRESSIVE EDUCATION AND DEVELOPMENT

Vol. 8, No. 2, 2019, E-ISSN: $2226-6348$ @ 2019 HRMARS

\section{Importance of Generic Skills}

Generic skills are important aspects that need to be mastered by students. It can be seen from some of the context of the national economy and the interests of the employer.

\section{National Development and Economic Development}

Malaysia by globalization requires people who can develop a country that can compete globally. Therefore, the state has to spend 30-40 per cent in education to build human resource strength that wish to achieve a successful result. The government's efforts are to ensure that educational institutions are able to produce quality students who have a balance of physical, emotional, spiritual and social development as stated in the National Education Philosophy.

In the 11th Malaysia Plan, the emphasis on improving the country's economy by Vision 2020. As such, it is a necessity to create a generation of not only excel in learning, but also the skills that will be essential to any country that generic skills or soft skills or also known availability of labor skills. Human capital development aspects are emphasized because it is variable to spur economic growth and support the transition of all sectors to knowledge-intensive activities (EPU, 2015).

11th Malaysia Plan is the latest five-year plan should be implemented as quickly as possible so that the main goal of Vision 2020 can be realized successfully. In addition, the National Transformation 2050 otherwise known as the N50, which was introduced in January this year also give emphasis to form Malaysia towards excellence in terms of economy, innovation and well-being (Berita Harian, 2017). Emphasis is given to the youth because they are the connectors to power the country's future. This group is desirable to equip themselves with various skills, knowledge, and become skilled human capital can boast countries globally. Ali Ibn Talib r.a. once quoted that,

"If you want to see the future of a country, then look at the youths today".

Allah says in Surah an-Nisa'ayat the 9th to the effect:

And they should fear God, supposing they leave behind offspring (generation) of the soil ".

To develop quality human capital for the country, the emphasis on the educational institution should be emphasized. This is because, through the educational institution it can train yourself up to date with the generation of knowledge that is useful in accordance with the will and desire of the State. Education at school level and tertiary level is aimed at human capital development systems provide education and training that focused on "Education for All" by the world (UNESCO, 2014).

Success in shaping society by 2020 is dependent on the effectiveness of business development and management of human capital through education and training institutions because it will enhance labor productivity, adaptability to labor skills and eventually restructure society in terms of employment (Akhbar Rencana, 2009). In human capital theory and approaches such as the rate of return has proved educational institutions working to improve the productivity 
and income of a person and thus encourage economic growth (Yussof, 2003). Even in the speech of former Malaysian Deputy Prime Minister YAB Tan Sri Dato 'Hj Muhyiddin Mohd conjunction with the Association of Employees in 2011 emphasized the role of education in nurturing knowledgeable citizen are as follows;

"Human capital is highly knowledgeable, and world-class quality is a necessity in the country's efforts to tap new sources of economic growth based on high technology. In this context, appropriate education and training institutions to make improvements in creative and innovative on education and training delivery system to enable the country to produce more workers who are not only skilled but also innovative and competitive ".

\section{Employer Requirements}

In addition to academic skills and technical skills, sector jobs now require them to have generic skills. These skills will help individuals to adapt to the changes and can be an effective factor to deal with the changing environment (Rasul et.al, 2014). Bennett et.al, (2000) stated the reasons having to generic skills is because of the need to be competitive in the industry. Second, the need to obtain new knowledge in the world based on knowledge (K-World), all three need to socialize and interact in the world of self-reliance as well as the latest workplace requirements. Hager et. al, (2002) states the generic skills or reliability work findings have provided suppression because of high demand from employers, both because of job demands that require them to deal with the change of the century and adapt themselves with the skills and party interests to educational institutions that need workers who can apply the generic skills. Chan (2000) stating the organization currently does not require labor intensive but requires a knowledgeable and highly skilled.

The high demand from employers led to educational institutions need to provide students with generic skills adequately. Buntat (2004) describes the number of generic skills or soft skills required by employers, self-management skills where skills need to be given close attention, namely the positive attitude skills, adaptive skills and responsibility skills. The second and third team skills academic skills such as problem solving, thinking skills, mastering math and communication skills.

Many other aspects which are required by the employer to the employee attitude and outlook for the future, mastery of basic skills such as ICT and languages, the ability to think creatively and critically, self-discipline, general knowledge and others spiritual (Arbaa, 2015). Generic or soft skills such as human relations skills, communication skills, ethical behavior and cognitive skills that he is a contributor will be considered by employers when selecting employees. The study conducted by Green (1999) for employers in Britain found, there was an increase in generic skills needs of each employer. Pumphery (2001) increased competition in the job requires employers to ensure the continued sustainability in the production of their company. Thus, employers need to produce workers with generic skills that all problems can be solved easily. 
Employer for the industry small, medium and large have requirements similar interest to the attitude of individuals in skill availability of work or generic skills, but the skills of communication, large industries, particularly those with many branches requires communication skills in the workplace (Rasul et. al, 2014). Buck,L.L., (1987) before one enters the realm of employment, the employer can demonstrate that they value responsibility, dignity, cooperation, self-discipline and show interest. The second phase, they were able to showcase the passion to learn and to solve problems. Natriello (1998) found that the employer puts aspects of the attitude to be owned by an employee, while the report of the Secretary's Commission on Achieving Necessary Skills (SCAN) Act 1991 also identifies seven competencies required by employers in the entry-level early employee of basic skills, information skills, interpersonal skills, resource skills, thinking skills, technology and quality systems and individuals. Makhbul et. al, (2012) of 534 respondents gave feedback from the 2000 questionnaire, which was mailed. The results indicated that personality factors and the skills and confidence to become the preferred choice of employers of graduates. Self-confidence followed by effective communication skills is an advantage for graduates to become the first-choice employer.

In addition, employers require three categories of skills that should possessed the knowledge which cover the known facts and concepts to understand, both skills that are used in the management and applications such as computer use, conduct experiments, analyze, design, evaluate, communicate, leadership and teamwork. The third is the attitude that leads to skills and knowledge such as personal values, concerns and trends. Therefore, the need of generic skills, or soft skills or availability of labor skills are needed by employers to improve the progress of the company.

Thus, the application of these skills needs to be implemented as early as possible starting at the school level, so, skills that they learned are able to help throughout the next stage of higher education into the working world in the future. The case studies carried out by IPPTN (2003) also found that in general, employers need workers who have communication skills with the characteristics of a good personal and knowledge in ICT.

\section{Conclusion}

Generic skills provide a major contribution to national development. Hence mastery of these skills is necessary to begin at school level up to university level. Therefore, a further study is needed to explore the implementation of generic skills, especially at school level so that these institutions can provide useful human capital for the country soon.

\section{Bibliography}

\section{Al Quran al Karim.}

Abbas, R. (2008). Kemahiran Insaniah: Meneroka Metodologi Rasulullah SAW (panduan Untuk Para Pendidik). Universiti Malaysia Malaysia.

Ahmad, E., Suhaili, P., \& Shariati, H. S. S. (2015). Lecturers' Perception of the Soft Skills of Engineering Students in Malaysian Polytechnics. Full Paper Proceeding GTAR, 2, 495.

Rencana, A. (2009, September 14). Manusia Modal Pertumbuhan Ekonomi. Retrieved from 
INTERNATIONAL JOURNAL OF ACADEMIC RESEARCH IN PROGRESSIVE EDUCATION AND DEVELOPMENT

Vol. 8, No. 2, 2019, E-ISSN: $2226-6348$ @ 2019 HRMARS

http://ww1.utusan.com.my/utusan/info.asp?y=2009\&dt=0914\&pub=Utusan_Malaysia\&se c=Rencana\&pg=re_08.htm

Amla, M. S. (2010). Pendidikan kerjaya dan pembangunan modal insan. Universiti Kebangsaan Malaysia

Arbaa, R. (2015). Kearifan tempatan profesional guru dalam menerapkan kemahiran insaniah di dalam bilik darjah(Doctoral dissertation, Universiti Sains Malaysia).

Arsat, M., \& Rahimi, S. D. (2011). Kemahiran generik dalam latihan industri terhadap pembentukan kerjaya jurutera di Dyson Manufacturing Sdn Bhd.Journal of Science \& Mathematics Education, 1-8.

Bennett, N., Dunne, E., \& Carré, C. (2000). Skills Development in Higher Education and Employment. Taylor \& Francis, Inc., 7625 Empire Dr., Florence, KY 41042

Berita Harian. (2017, June 9). Pengangguran Antara Cabaran TN50. Berita Harian. Retrieved from https://www.bharian.com.my/node/291183

Buck, L. L., \& Barrick, R. K. (1987). They're Trained, But Are They Employable?. Vocational Education Journal, 62(5), 29-31.

Buntat, Y. (2004). Integrasi kemahiran"employability"dalam program pendidikan vokasional pertanian dan industri di Malaysia (Doctoral dissertation, Universiti Teknologi Malaysia).

Chan, Y. F. (2000). Preparing Knowledge Workers for the Knowledge Economy. Education, Journal of Technology and Vocational Future, : Globalization and Trends.

Clayton, B., Blom, K., Meyers, D., \& Bateman, A. (2003). Assessing and certifying generic skills: what is happening in vocational education and training?. National Centre for Vocational Education Research (NCVER). South Australia.

Darulsalam, G. (2004). Pedagogi Pendidikan Islam. Utusan Publication \& Distributors Sdn Bhd.

Department of Institutional Management of Higher Education. (2006). Modul Pembangunan Kemahiran Insaniah (Soft Skills) Untuk Institusi Pengajian Tinggi Malaysia. Universiti Putra Malaysia.

Department of Statistics. (2016, Jun 20). Statistik Utama Tenaga Buruh di Malaysia. Retrieved from https://www.dosm.gov.my/v1/\#

EPU. (2015, Jun 19). Meningkatkan pembangunan modal insan untuk negara maju. Economic Development Unit, Bab 5, 36. Retrieved from http://rmk11.epu.gov.my/book/bm/Bab5/Bab 5.pdf

Green, F. (1999). The market value of generic skills. Sheffield: Department for Education and Employment.

Hager, P., Holland, S., \& Beckett, D. (2002). Enhancing the learning and employability of graduates: The role of generic skills. B-Hert Position Paper, 9.

IPPTN. (2003). Kajian Masalah Pengangguran di Kalangan Siswazah. Institut Penyelidikan Pendidikan Tinggi Negara.

Khir, K. (2006). Training Approach for the Employability of Graduates: Critical Graduate Competencies in the Changing World. In National Conference on Continuing Technical Education \& Training.

Kearns, P. (2001). Generic skills for the new economy: A review of research relating to generic skills. National Center for Vocational Education Research, Adelaide.

Makhbul, Z. M., Yussof, I., \& Awang, A. H. (2012). Kriteria Pengambilan dan Pemilihan Graduan 
dari Perspektif Pengurusan Sumber Manusia. Jurnal Personalia Pelajar, 15(15), 1-11. https://doi.org/0128-273

Nabi, G. R., \& Bagley, D. (1998). Graduates' perceptions of transferable personal skills and future career preparation in the UK. Career Development International, 3(1), 31-39.

Natriello, G. J. (1998). The new Regents High School graduation requirements: Curricular and instructional implications and estimates of resources necessary to meet the new standards. New York, NY: Community Service Society of New York.

Pumphery, J. (2001). Skill Dialogues: Listening to Employers. A Comprehensive Sunmary of Generic Skills Requirement. Paper Research the Council for Administration.London.

Rasul, M. S., Husain, M. Y., \& Rauf, R. A. A. (2014). Kemahiran kebolehdapatan kerja: suatu keperluan pekerjaan. Penerbit Universiti Kebangsaan Malaysia.

Regel, O., Salmi, J., Watkins, A., Tan, H., Dawkins, J., Saroyan, A., \& Vestergaard, J. (2007). Malaysia and the Knowledge Economy: Building a World-Class Higher Education System. Human Development Sector Reports. World Bank Publications.

Ripin, M. N., Awang, R., \& Al-Jauhariyy, Z. H. (2012). Kemahiran generik menurut perspektif Islam. Penerbit UTM Press.

Stapa, Z., Ismail, A. M., \& Yusuf, N. (2012). Faktor Persekitaran Sosial Dan Hubungannya Dengan Pembentukan Jati Diri (Social Environmental Factors And Their Relation To Identity Formation). Jurnal Hadhari: An International Journal, 155-172.

Suhid, A. (2007). Pengajaran adab \& akhlak Islam dalam membangunkan modal insan. Jurnal Pengajian Umum Bil, 8, 167.

Unesco. (2014). Teaching and learning: Achieving quality for all. (Education for All Global Monitoring Report 2013/4).

Wibrow, B. (2011). Employability Skills. At a Glance. National Centre for Vocational Education Research Ltd. PO Box 8288, Stational Arcade, Adelaide, SA 5000, Australia.

Yussof, I. (2003). Pelaburan pendidikan tinggi: Analisis perbandingan IPTA-IPTS di Malaysia. Jurnal Pendidikan, 28, 33-46.

\section{Corresponding Author}

Maizatul Suraya Muhammad Nor,

Faculty of Education, The National University of Malaysia 43600 UKM Bangi, Selangor, Email: surayaukm@gmail.com 